\title{
TRIBOLOGICAL INVESTIGATION OF BORON CARBIDE FILMS SLIDING AGAINST DIFFERENT MATING MATERIALS UNDER HIGH RELATIVE HUMIDITY
}

\author{
XUEQIAN CAO*,*****, LUNLIN SHANG*, YONGMIN LIANG**, ${ }^{*}$ ZHIBIN LU*, \\ ${ }^{\#}$ GUANGAN ZHANG*, QUNJI XUE*
*State Key Laboratory of Solid Lubrication, Lanzhou Institute of Chemical Physics, Chinese Academy of Sciences, Lanzhou 730000, China
**State Key Laboratory of Applied Organic Chemistry, Lanzhou University, Lanzhou 730000, China
***Center of Materials Science and Optoelectronics Engineering, University of Chinese Academy of Sciences, \\ Beijing 100049, China
}

"E-mail: zblu@licp.cas.cn; gazhang@licp.cas.cn

Submitted April 13, 2019; accepted August 5, 2019

Keywords: $\mathrm{B}_{4} \mathrm{C}$ film, Friction and wear, Mating material, Normal load, Sliding frequency

\begin{abstract}
Tribological performances are significantly affected by the tribo-chemical reaction of the mating materials, while the effect on the $B_{4} C$ film under high relative humidity conditions are poorly investigated. Therefore, fiction tests of three tribo-pairs $\left(B_{4} C / W C, B_{4} C /\right.$ steel and $\left.B_{4} C / A_{2} O_{3}\right)$ under $85 \%$ RH with various normal loads and sliding frequencies were performed. The results show that the $B_{4} C / W C$ tribo-pair exhibits excellent tribological properties, including very stable friction curves, minimum friction coefficients \& wear rates, maximum carrying-load capacity and the smallest fluctuations with the change of the normal load. Similar results have been obtained for the $B_{4} C / W C$ tribo-pair with the increase in the sliding frequency. This is mainly attributed to the oxidation of $W C$ to form $\mathrm{WO}_{3}$ that is conducive in enhancing the tribological performances. Therefore, the sliding contact of $B_{4} C / W C$ is the desirable design for engineering applications under high relative humidity.
\end{abstract}

\section{INTRODUCTION}

Boron carbide $\left(\mathrm{B}_{4} \mathrm{C}\right)$, one of the most important engineering ceramics, has been extensively used in various industrial fields of cutting tools [1], nozzles [2], astronomical applications [3], ballistic armour [4], thermal neutron detectors [5] and as an enhancing phase in alloys [6-8], because its special atomic structure and composition lends itself to outstanding physical and mechanical properties [9-13], such as a high melting point $\left(2450{ }^{\circ} \mathrm{C}\right)$, high hardness $(30 \sim 45 \mathrm{GPa})$, excellent chemical inertness, low density $\left(2.52 \mathrm{~g} \cdot \mathrm{cm}^{-3}\right)$ and strong absorption neutron ability. Nevertheless, the high friction coefficient of $\mathrm{B}_{4} \mathrm{C}(0.4 \sim 0.9)$ seriously impedes its further application.

Based on this situation, several strategies have been adopted to reduce the friction coefficient, such as a pre-heat treatment [14], increasing the relative humidity (RH) [15-17] and adding additives [18-21]. Erdemir et al. [14] reported that boron oxide $\left(\mathrm{B}_{2} \mathrm{O}_{3}\right)$ and boric acid $\left(\mathrm{H}_{3} \mathrm{BO}_{3}\right)$ were formed on the hot-pressed $\mathrm{B}_{4} \mathrm{C}$ surface after an annealing treatment, and hence the annealed $\mathrm{B}_{4} \mathrm{C}$ achieved a much lower friction coefficient $(0.03 \sim 0.05)$. Larsson et al. reported that with relative humidity increasing from $20 \%$ to $100 \%$, the friction coefficients of the hot isostatically pressed $\mathrm{B}_{4} \mathrm{C}$ decrease from $\sim 0.4$ to $\sim 0.12$ and the wear rates decrease from $10^{-2} \mathrm{~mm}^{3} \cdot \mathrm{m}^{-1} \cdot \mathrm{N}^{-1}$ to $10^{-4} \mathrm{~mm}^{3} \mathrm{~m}^{-1} \cdot \mathrm{N}^{-1}$. Cuong et al. [22] investigated the influence of the relative humidity on the friction and wear behaviours of $\mathrm{B}_{4} \mathrm{C}$ films and revealed that a lower friction coefficient and a higher wear resistance were achieved under a higher relative humidity. Li and Gao et al.[19] investigated that the effect of the hBN content on the tribological characteristics of $\mathrm{B}_{4} \mathrm{C}-\mathrm{hBN}$, and found that the $\mathrm{B}_{4} \mathrm{C}$ pin/ $/ \mathrm{B}_{4} \mathrm{C}-20 \mathrm{wt}$. $\% \mathrm{hBN}$ disc tribo-pair achieved the best overall tribological performances under a sliding condition with $50 \pm 10 \%$ RH. Using AISI 52100 steel as a disc, they [20] further studied the effect of the hBN content under the sliding condition and found that the lowest friction coefficient and wear rates of the pin and disc were obtained for the $\mathrm{B}_{4} \mathrm{C}-10 \mathrm{wt}$. \% hBN pin/steel disc tribo-pair. In addition, they [21] also studied the tribological properties of $\mathrm{B}_{4} \mathrm{C}-\mathrm{hBN}$ under water lubrication, and found that the $\mathrm{B}_{4} \mathrm{C}-20$ wt. $\%$ hBN pin/AISI 321 steel disc tribo-pair achieved a super low friction coefficient of about 0.008 after a sliding distance of about $500 \mathrm{~m}$.

Tribological performances are significantly affected by the mating materials, which could lead to different tribological behaviours under the same condition. 
However, the influence on the $\mathrm{B}_{4} \mathrm{C}$ film is poorly investigated, because the previous studies only selected a single tribo-pair, and just paid close attention to the tribo-chemical reactions of $\mathrm{B}_{4} \mathrm{C}$, but lost sight of the mating materials. According to the reported investigations, however, some interesting phenomena are still found. Friction and wear experiments of hot-pressed $\mathrm{B}_{4} \mathrm{C}$ sliding against $440 \mathrm{C}$ steel[14] and $\mathrm{ZrO}_{2}$ [23] in the open air with $50 \pm 5 \%$ RH were studied by Erdemir et al. and the friction coefficients are $0.6 \sim 0.7$ and $0.3 \sim 0.4$, respectively. In a previous work [17], we performed tribological tests on $\mathrm{B}_{4} \mathrm{C}$ films sliding against different mating materials and found that the tribological performances of the $\mathrm{B}_{4} \mathrm{C} / \mathrm{WC}$ tribo-pair is much better than those of the $\mathrm{B}_{4} \mathrm{C} / \mathrm{Al}_{2} \mathrm{O}_{3}$ and $\mathrm{B}_{4} \mathrm{C} /$ steel tribo-pairs under $55 \sim 85 \% \mathrm{RH}$ conditions. High relative humidity $(85 \% \mathrm{RH})$ is one of common and important engineering application conditions, in which friction systems often operate at different normal loads and sliding speeds (or frequencies). However, previous friction tests [17] under $85 \% \mathrm{RH}$ only performed under a single normal load and speed ( $2 \mathrm{~N}$ and $5 \mathrm{~Hz}$ ). And hence, it is necessary to further investigate the effect of the mating material on the tribological performances of the $\mathrm{B}_{4} \mathrm{C}$ film under a high relative humidity $(85 \% \mathrm{RH})$ with various normal loads and sliding frequencies.

In this brief investigation, we further performed the friction tests on the $\mathrm{B}_{4} \mathrm{C}$ film under $85 \% \mathrm{RH}$ condition, focusing on the effects of the mating material, normal load and sliding frequency. Three mating materials were applied: a tungsten carbide (WC) ball for its excellent mechanical properties, an AISI 52100 steel ball for its wide applications and an alumina $\left(\mathrm{Al}_{2} \mathrm{O}_{3}\right)$ ball for its outstanding chemical inertness. The $\mathrm{B}_{4} \mathrm{C} / \mathrm{WC}$ tribo-pair exhibits excellent comprehensive tribological properties, and hence, it is the desirable design for high humidity engineering applications.

\section{EXPERIMENTAL}

The amorphous $\mathrm{B}_{4} \mathrm{C}$ films about $1.46 \mu \mathrm{m}$ thick were prepared on polished AISI 304 stainless steel plates by sputtering one $\mathrm{B}_{4} \mathrm{C}$ target and two $\mathrm{Cr}$ targets using a closed field unbalanced magnetron sputtering equipment (UPD 650, Teer Coatings Ltd). In addition, a thin $\mathrm{Cr}$ interlayer about $200 \mathrm{~nm}$ was deposited on the top surface of the substrates to improve the adhesion. The specific deposition parameters and properties of the $\mathrm{B}_{4} \mathrm{C}$ film (shown in Table 1) were described in our previous article [17].

Friction and wear tests of the $\mathrm{B}_{4} \mathrm{C}$ film under high relative humidity $(85 \% \mathrm{RH})$ were carried out on a ballon-disk tribometer (CSM) in a reciprocating mode. Prior to the tribological tests, the samples and counter balls were cleaned with ethanol in an ultrasonic bath. All the tests were tested for 10000 revolutions, at room temperature and with a stroke length of $5 \mathrm{~mm}$. The $\mathrm{Al}_{2} \mathrm{O}_{3}$, Steel and WC ball with a radius of $3 \mathrm{~mm}$ were applied in the friction tests and those properties are shown in Table 2. With the frequency of $5 \mathrm{~Hz}$, normal loads were maintained at $1,3,5,7,10$ and $15 \mathrm{~N}$, and the corresponding Hertzian contact pressures are shown in Table 3. At a normal load of $5 \mathrm{~N}$, the frequencies were set as 1,3,5 Hz. Each experiment was performed at least three times to check the reliability of the tribological behaviours.

Table 3. Hertz contact pressures of each tribo-pair under various normal loads.

\begin{tabular}{lccccccc}
\hline Ball & $1 \mathrm{~N}$ & $2 \mathrm{~N}$ & $3 \mathrm{~N}$ & $5 \mathrm{~N}$ & $7 \mathrm{~N}$ & $10 \mathrm{~N}$ & $15 \mathrm{~N}$ \\
$\mathrm{WC}$ & 820 & 1033 & 1183 & 1402 & 1569 & 1767 & 2022 \\
$\mathrm{Steel}$ & 637.0 & 802.3 & 918.7 & 1089 & 1219 & 1372 & - \\
$\mathrm{Al}_{2} \mathrm{O}_{3}$ & 722.9 & 910.8 & 1043 & 1236 & 1383 & - & - \\
\hline
\end{tabular}

After each sliding test, the average disc wear loss with the corresponding standard deviations was obtained from at least three locations by an optical profiler (KLA Tencor D-100), and then the specific disc wear rate [disc wear loss / (normal load $\times$ total sliding distance)] was calculated. The surface characterisations of the disc wear track and ball wear scars were performed on a scanning electron microscope (SEM, JSM-5600LV) with an energy dispersive spectrometer (EDS).

Table 1. Properties of the $\mathrm{B}_{4} \mathrm{C}$ film.

\begin{tabular}{cccccc}
\hline Thickness & Contact angle & Hardness & Elastic modulus & Roughness & Adhesion force \\
\hline$\sim 1.46 \mu \mathrm{m}$ & $67.6 \pm 2.77^{\circ}$ & $32.4 \pm 0.8 \mathrm{GPa}$ & $280 \pm 9.7 \mathrm{GPa}$ & $11.5 \pm 0.6 \mathrm{~nm}(\mathrm{Ra})$ & $20 \pm 0.3 \mathrm{~N}$ \\
\hline
\end{tabular}

Table 2. Properties of the tribo-pair balls in the friction tests.

\begin{tabular}{lcccc}
\hline Ball & $\begin{array}{c}\text { Hardness } \\
(\mathrm{GPa})\end{array}$ & $\begin{array}{c}\text { Elastic modulus } \\
(\mathrm{GPa})\end{array}$ & $\begin{array}{c}\text { Poisson } \\
\text { ratio }\end{array}$ & $\begin{array}{c}\text { Thermal conductivity } \\
\left(\mathrm{W} \cdot \mathrm{m}^{-1} \cdot \mathrm{K}^{-1}\right)\end{array}$ \\
\hline $\mathrm{Al}_{2} \mathrm{O}_{3}$ & 11.8 & 210 & 0.3 & 2 \\
$\mathrm{Steel}$ & 6.2 & 200 & 0.3 & 40 \\
$\mathrm{WC}$ & 14.6 & 635 & 0.22 & 79.6 \\
\hline
\end{tabular}




\section{RESULTS AND DISCUSSION}

Friction tests performed under various normal loads and frequencies

Figure 1a shows the frictional curves of the $\mathrm{B}_{4} \mathrm{C} /$ WC tribo-pair at different loads with $85 \% \mathrm{RH}$. They are very stable throughout the normal load range and share a common feature: those curves start with low values and then increase to peaks, finally rapidly reaching steadystate values. It is seen from Figure $1 b$ that the stable friction coefficients decrease at first and then increase, and the minimum value $(\sim 0.10 \pm 0.01)$ is obtained at $5 \mathrm{~N}$. Besides, the wear rates just fluctuate in a small range of $4.55 \pm 0.28 \sim 5.94 \pm 0.29 \times 10^{-7} \mathrm{~mm}^{3} \cdot \mathrm{m}^{-1} \cdot \mathrm{N}^{-1}$ as the normal load increases from $3 \mathrm{~N}$ to $15 \mathrm{~N}$.

Figure $2 \mathrm{a}$ presents the frictional curves of the $\mathrm{B}_{4} \mathrm{C}$ film sliding against the steel ball with various loads under $85 \%$ RH. The frictional curves share a different run-in behaviour from the $\mathrm{B}_{4} \mathrm{C} / \mathrm{WC}$ tribo-pair: they drop directly to its steady stage after a short running in period (500 runs or even less). In addition, the $\mathrm{B}_{4} \mathrm{C}$ film fails at $\sim 6500$ cycles at the normal load of $10 \mathrm{~N}$. It is observed from Figure $2 b$ that the stable friction coefficients and wear rates at first decrease and then increase. At the normal load of $5 \mathrm{~N}$, the $\mathrm{B}_{4} \mathrm{C} / \mathrm{Steel}$ tribo-pair achieves the lowest friction coefficient $(0.14 \pm 0.02)$ and wear rate $\left(7.12 \pm 0.18 \times 10^{-7} \mathrm{~mm}^{3} \cdot \mathrm{m}^{-1} \cdot \mathrm{N}^{-1}\right)$.

Figure 3a exhibits the frictional curves between the $\mathrm{B}_{4} \mathrm{C}$ film and $\mathrm{Al}_{2} \mathrm{O}_{3}$ ball under various loads with $85 \%$ $\mathrm{RH}$. They share a similar run-in behaviour with the $\mathrm{B}_{4} \mathrm{C} /$ Steel tribo-pair. Moreover, the friction coefficient of $7 \mathrm{~N}$ at $\sim 8700$ revolutions presents a sudden rise to 0.55 , suggesting that the film was worn through. As shown in Figure $3 b$, as the applied load increases, both the stable friction coefficients and wear rates decrease at first and then increase, and the minimum friction coefficient $(0.12 \pm 0.01)$ and wear rate $\left(19.1 \pm 2.43 \times 10^{-7} \mathrm{~mm}^{3} \cdot \mathrm{m}^{-1} \cdot \mathrm{N}^{-1}\right)$ are obtained at $3 \mathrm{~N}$.

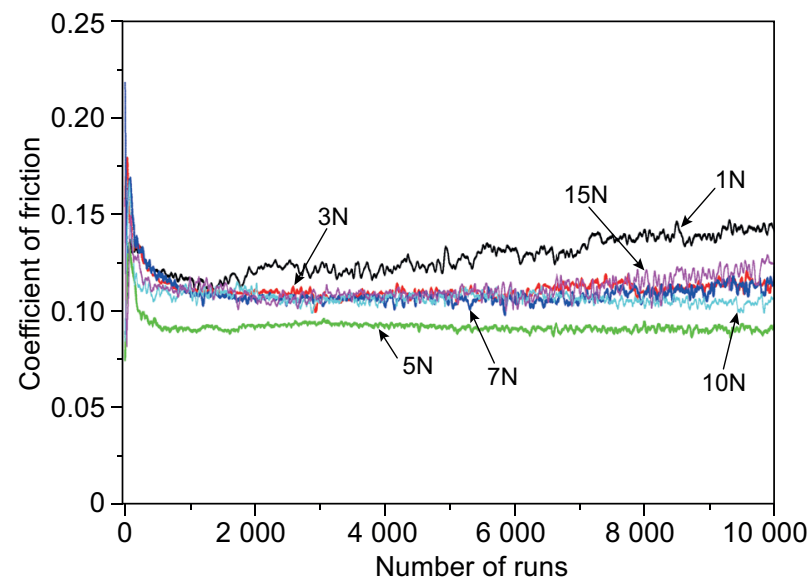

a)

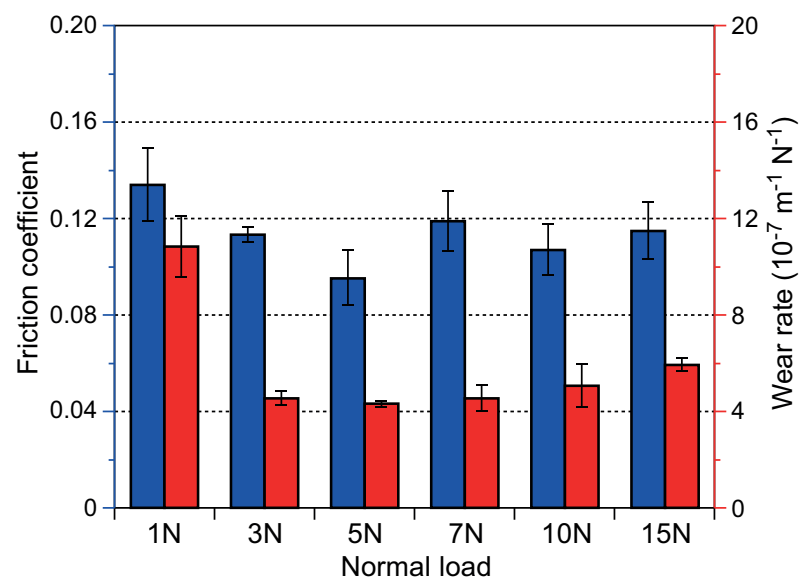

b)

Figure 1. The tribological properties of the $\mathrm{B}_{4} \mathrm{C} / \mathrm{WC}$ tribo-pair with $85 \% \mathrm{RH}$ at $5 \mathrm{~Hz}$.

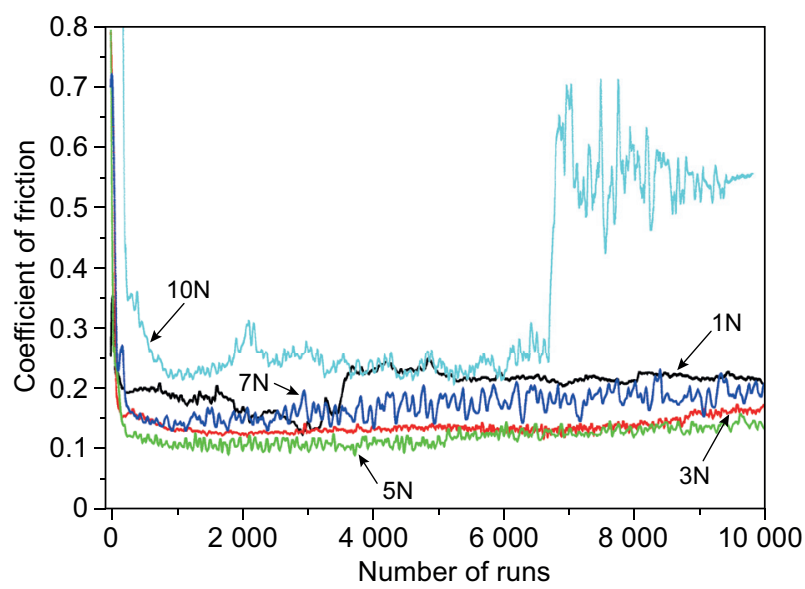

a)

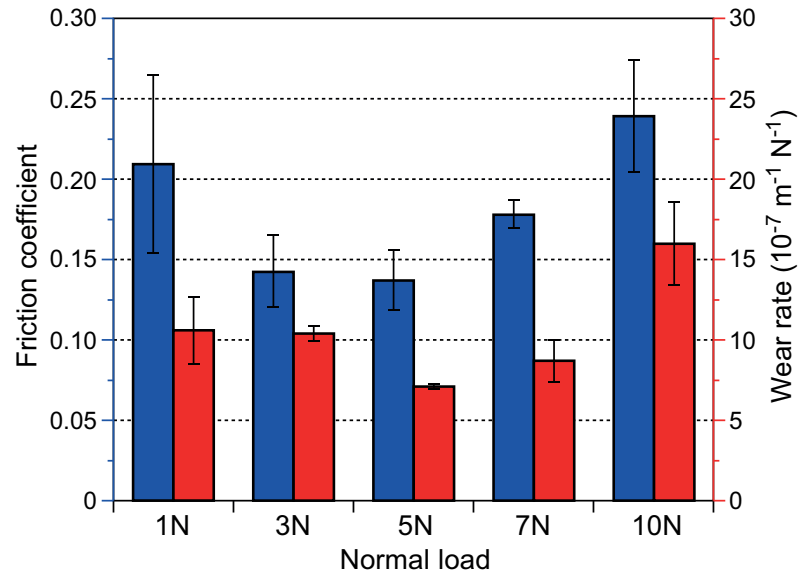

b)

Figure 2. The tribological behaviours of the $\mathrm{B}_{4} \mathrm{C} /$ Steel tribo-pair with $85 \% \mathrm{RH}$ at $5 \mathrm{~Hz}$. 


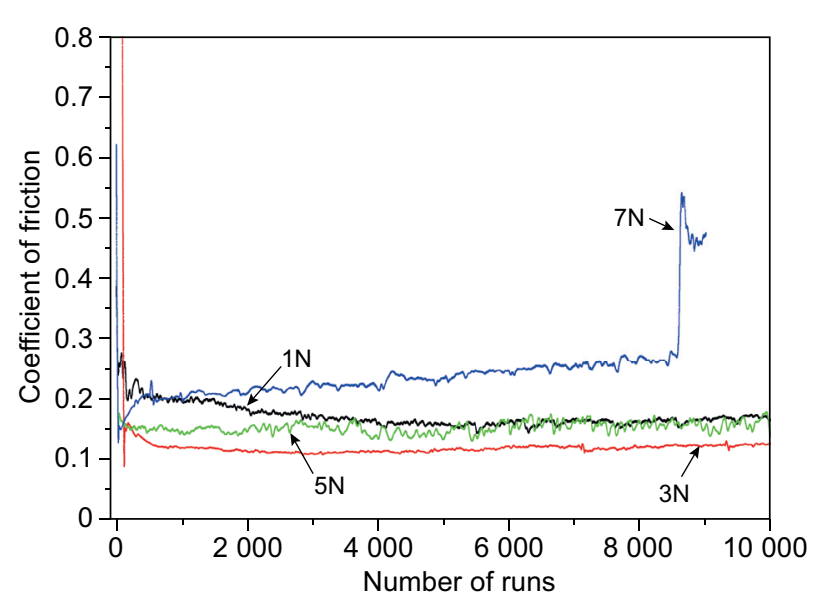

a)

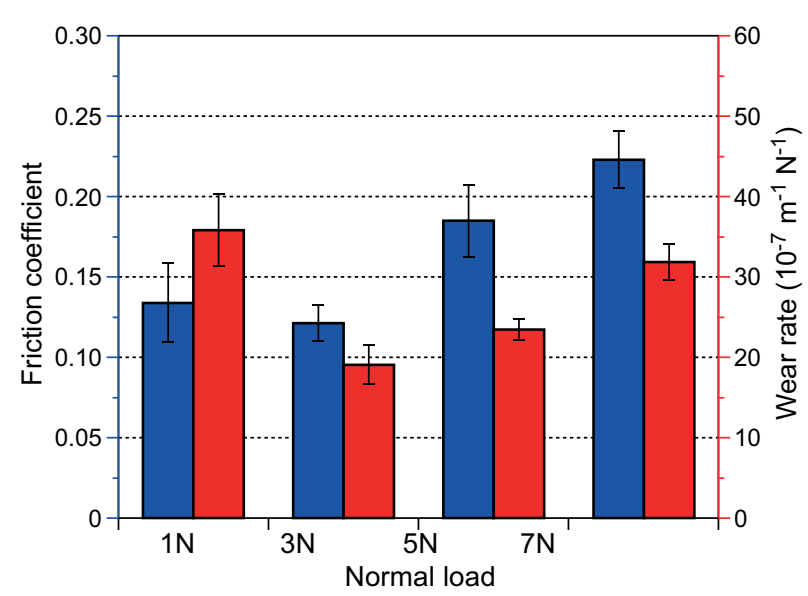

b)

Figure 3. The tribological performances of the $\mathrm{B}_{4} \mathrm{C} / \mathrm{Al}_{2} \mathrm{O}_{3}$ tribo-pair with $85 \% \mathrm{RH}$ at $5 \mathrm{~Hz}$.

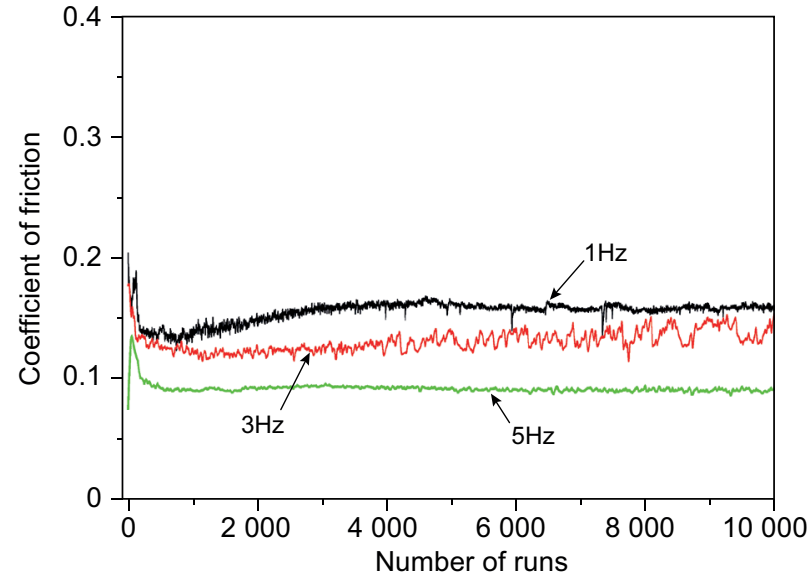

a)

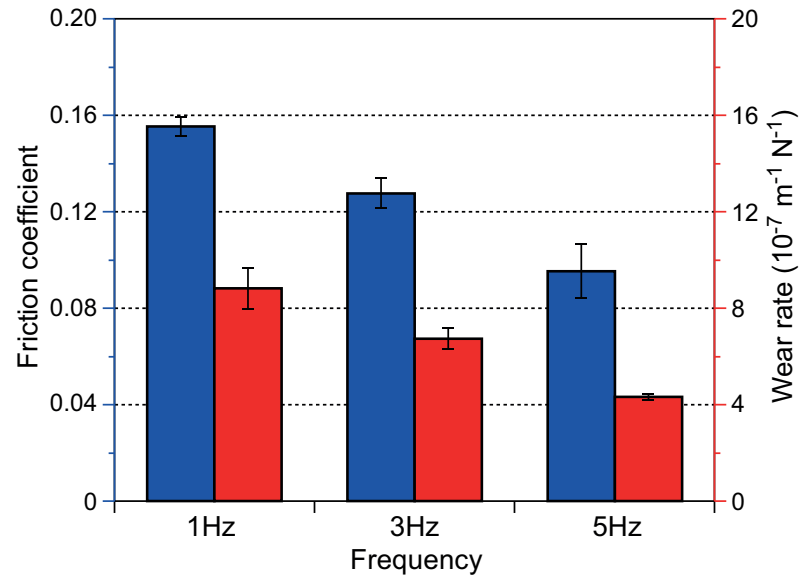

b)

Figure 4. The tribological performances of the $\mathrm{B}_{4} \mathrm{C} / \mathrm{WC}$ tribo-pair with $85 \% \mathrm{RH}$ at $5 \mathrm{~N}$.

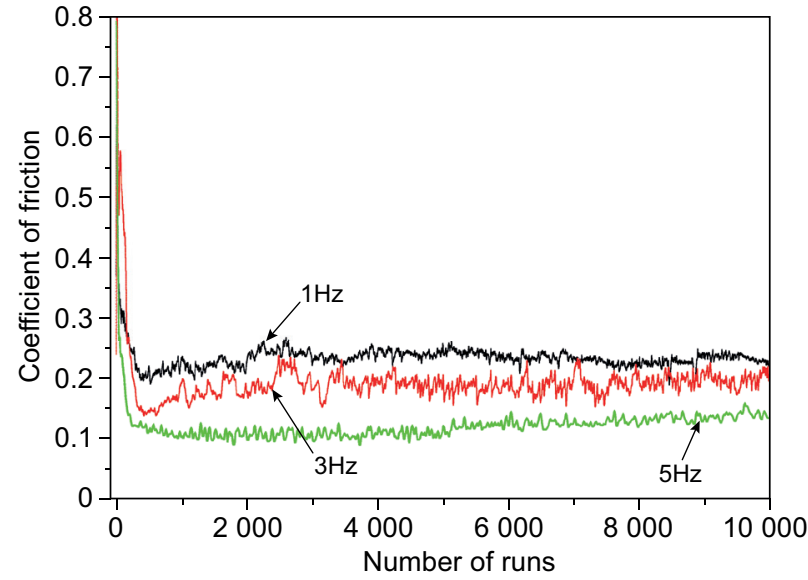

a)

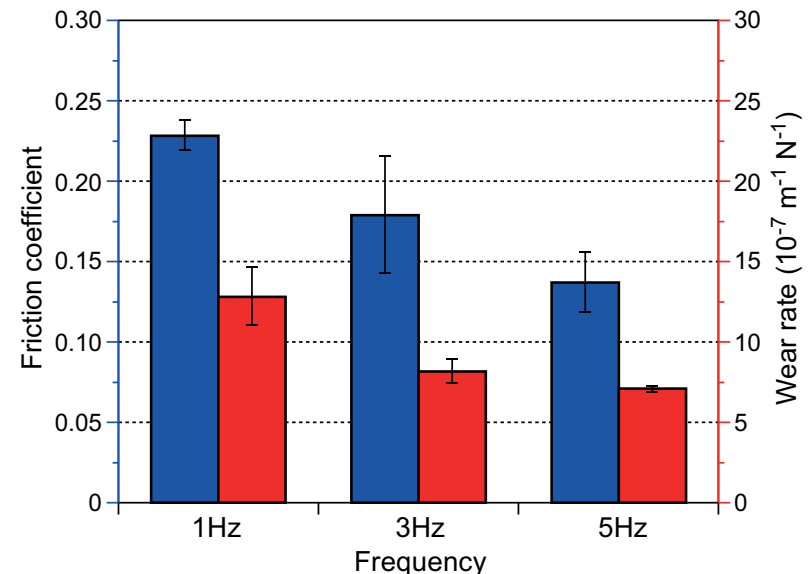

b)

Figure 5. The tribological performances of the $\mathrm{B}_{4} \mathrm{C} /$ Steel tribo-pair with $85 \% \mathrm{RH}$ at $5 \mathrm{~N}$. 


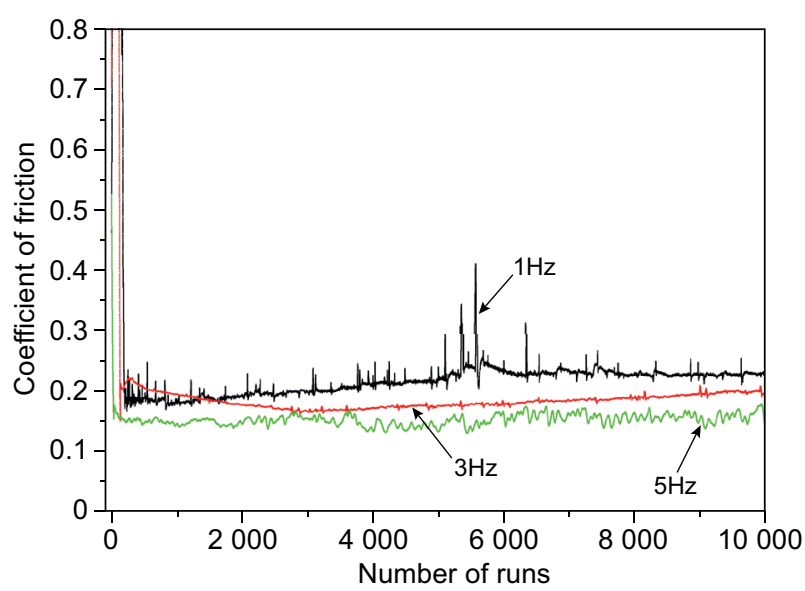

a)

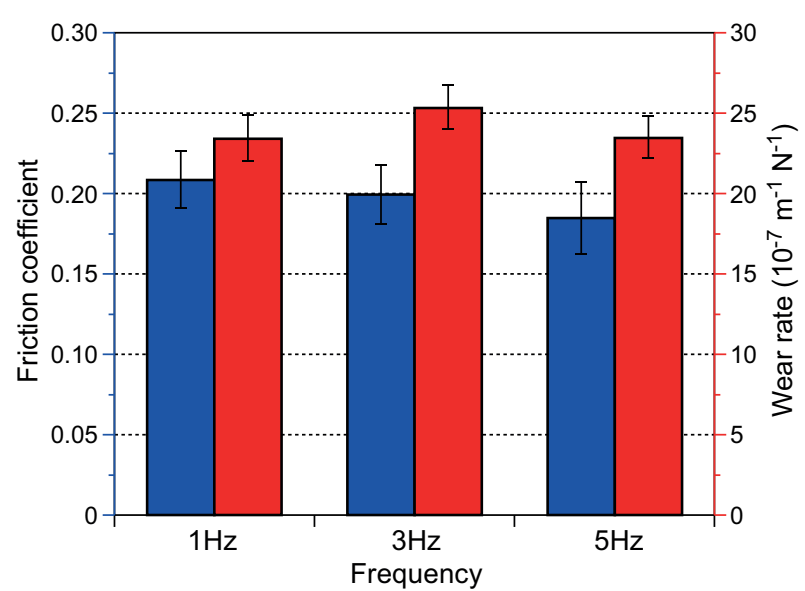

b)

Figure 6. The tribological performances of the $\mathrm{B}_{4} \mathrm{C} / \mathrm{Al}_{2} \mathrm{O}_{3}$ tribo-pair with $85 \% \mathrm{RH}$ at $5 \mathrm{~N}$.

The frictional curves of the $\mathrm{B}_{4} \mathrm{C} / \mathrm{WC}$ tribo-pair at various frequencies with $85 \% \mathrm{RH}$ are presented in Figure 4. It is found that the frictional curves of the $\mathrm{B}_{4} \mathrm{C} / \mathrm{WC}$ tribo-pair rapidly reach steady-state after short run-in periods. Similar phenomena are also observed in the $\mathrm{B}_{4} \mathrm{C} /$ Steel (Figure 5) and $\mathrm{B}_{4} \mathrm{C} / \mathrm{Al}_{2} \mathrm{O}_{3}$ (Figure 6) tribopairs. Meanwhile, with the increase in the frequency, the friction coefficients for the $\mathrm{B}_{4} \mathrm{C} / \mathrm{WC}$ and $\mathrm{B}_{4} \mathrm{C} /$ Steel tribo-pairs have an obvious decrease, while that of the $\mathrm{B}_{4} \mathrm{C} / \mathrm{Al}_{2} \mathrm{O}_{3}$ tribo-pair just exhibits a slight decrease. A similar trend can also be found in the wear rates.

\section{SEM analysis of the disc wear tracks and ball wear scars}

To explore the friction and wear mechanisms of the $\mathrm{B}_{4} \mathrm{C}$ film, the disc wear tracks and ball wear scars tested at $5 \mathrm{~N}, 5 \mathrm{~Hz}$ and $85 \% \mathrm{RH}$ condition were investigated by SEM and EDS. Figure 7 presents the SEM images and EDS maps of the $\mathrm{B}_{4} \mathrm{C}$ film and $\mathrm{WC}$ ball. The inside of the disc wear track and ball wear scar are very smooth and there are some abrasive particles outside of the disc wear track (Figure 7a) in which a slight concentration of the $\mathrm{O}$ element is observed. Moreover, as shown in Figure $7 \mathrm{~b}$, there are some abrasive plates at the edge of ball wear scar where a remarkable high concentration of the $\mathrm{O}$ element is seen. This indicates that a thin tribo-chemical film containing $\mathrm{WO}_{3}$ was continuously produced and pushed to the outside of the ball wear scar to form abrasive plates during the friction process.

As shown in Figure 8a, there are more abrasive particles outside the disc wear track for the $\mathrm{B}_{4} \mathrm{C} /$ Steel tribo-pair and there is a clear accumulation of $\mathrm{O}$ inside of the disc wear track. In addition, it can be observed from Figure $8 \mathrm{~b}$ that an obvious high concentration of the $\mathrm{O}$ element is observed around the ball wear scar and a slight accumulation of the $\mathrm{B}$ element is found inside the ball wear scar. This implies that both the $\mathrm{B}_{4} \mathrm{C}$ film and steel ball were oxidised during the friction test and the ball wear debris contains some boron oxide $\left(\mathrm{B}_{2} \mathrm{O}_{3}\right)$
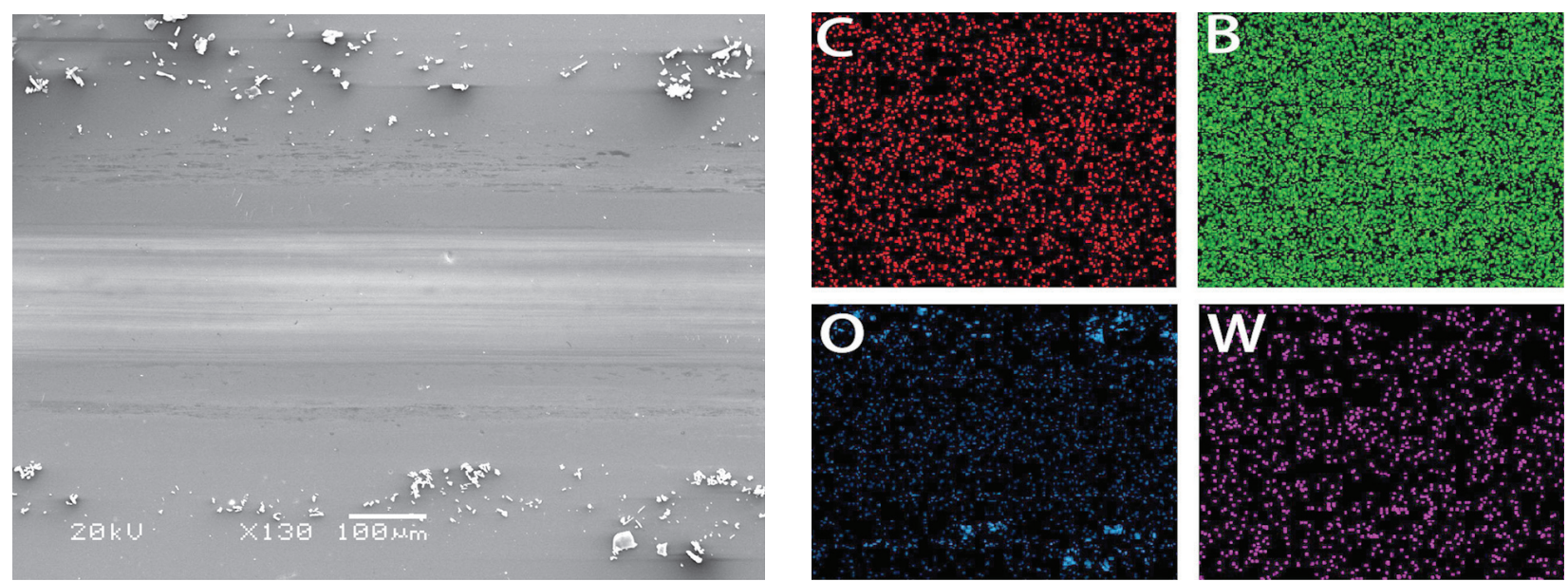

a)

Figure 7. The SEM images and EDS maps of the $\mathrm{B}_{4} \mathrm{C}$ film (a) tested at $5 \mathrm{~N}, 5 \mathrm{~Hz}$ and $85 \% \mathrm{RH}$. (Continue on next page) 

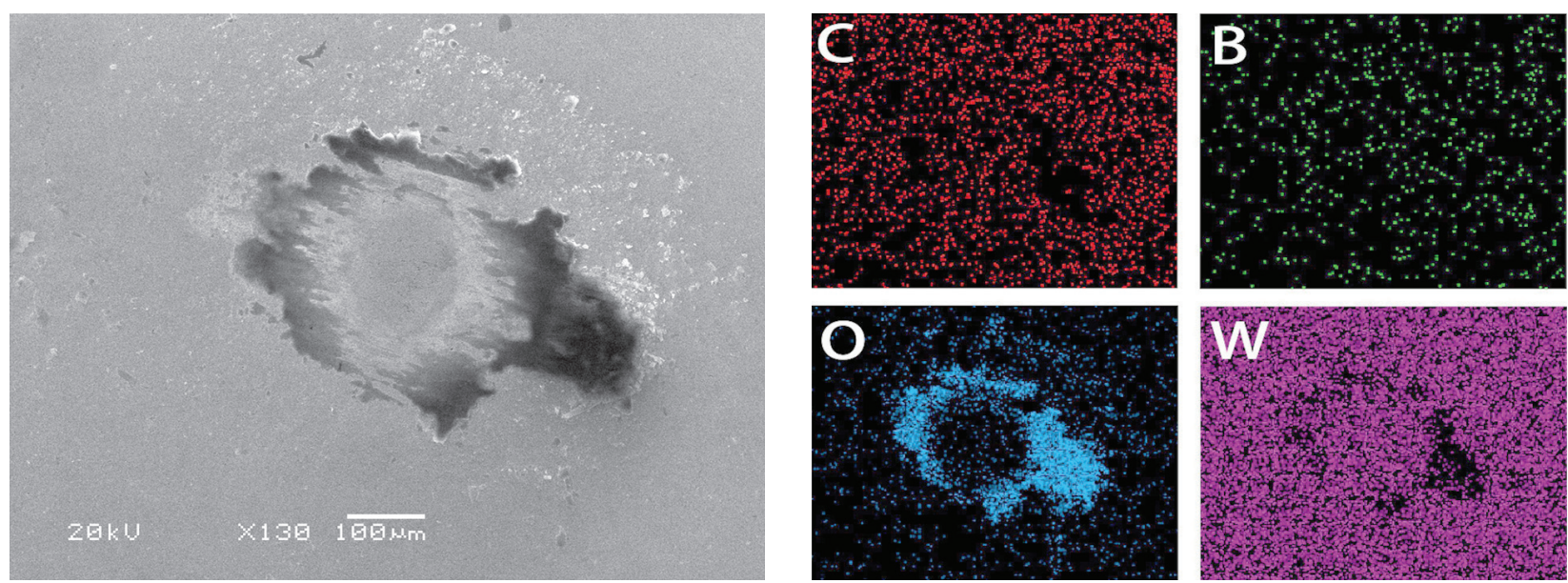

b)

Figure 7. The SEM images and EDS maps of the WC ball (b) tested at $5 \mathrm{~N}, 5 \mathrm{~Hz}$ and $85 \% \mathrm{RH}$.

or boric acid $\left(\mathrm{H}_{3} \mathrm{BO}_{3}\right)$. Thus, similar with the $\mathrm{B}_{4} \mathrm{C} / \mathrm{WC}$ tribo-pair, a thin tribo-chemical film might be also formed during the test. It is seen from Figure 9a that there are lots of abrasive grains and many tiny cracks
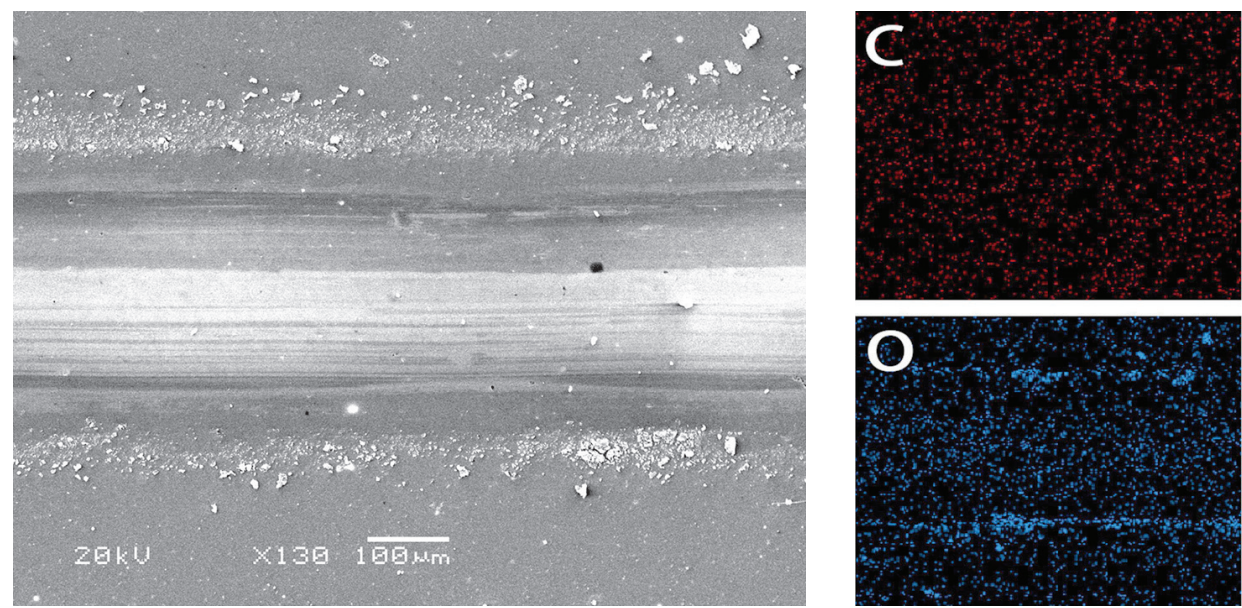

a)
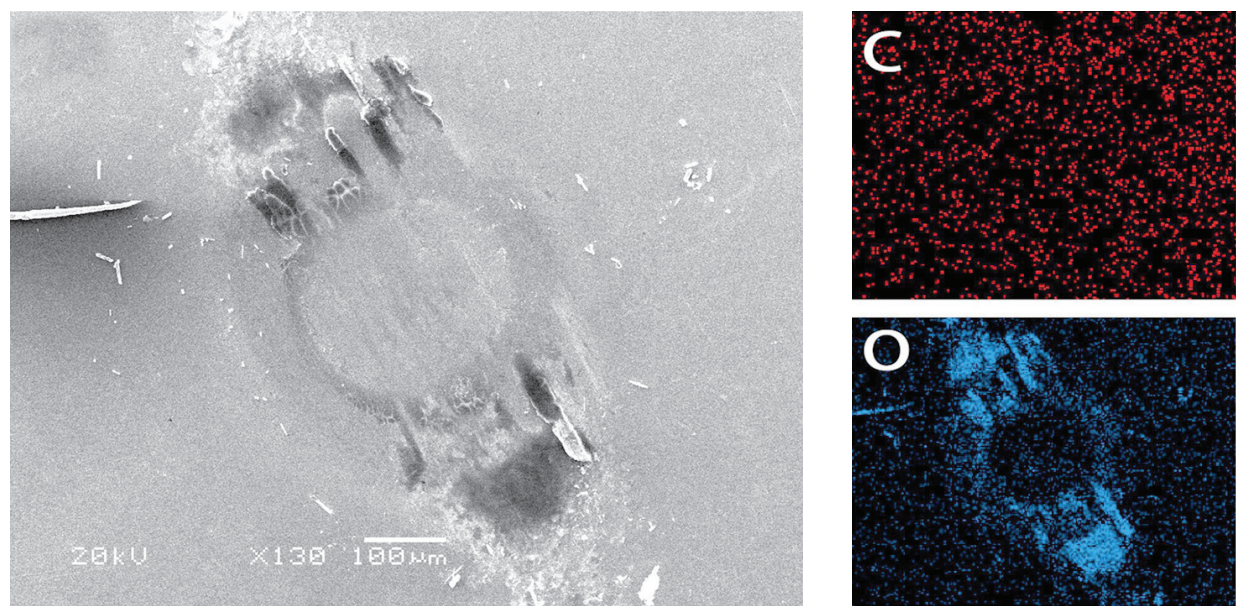

b)
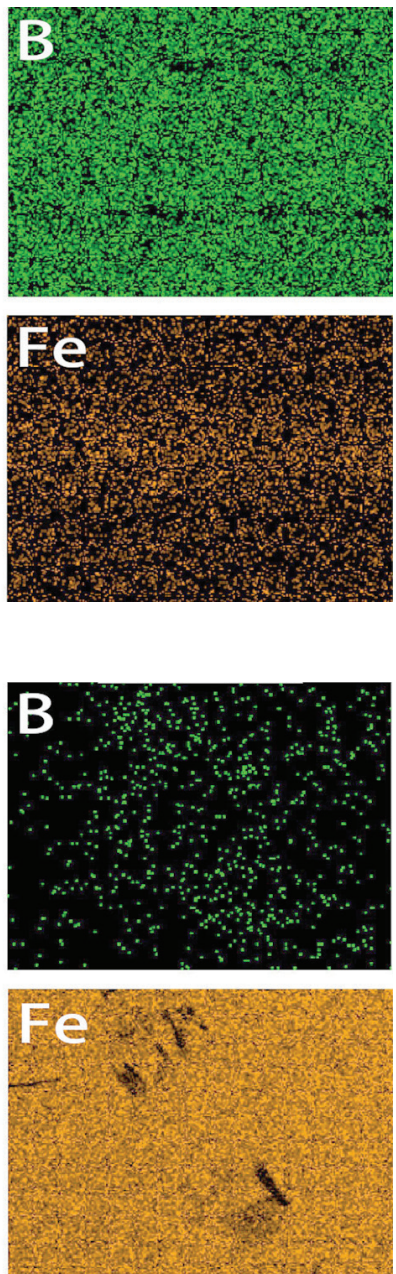

Figure 8. The SEM images and EDS maps of the $\mathrm{B}_{4} \mathrm{C}$ film (a) and the steel ball (b) tested at $5 \mathrm{~N}, 5 \mathrm{~Hz}$ and $85 \% \mathrm{RH}$. 

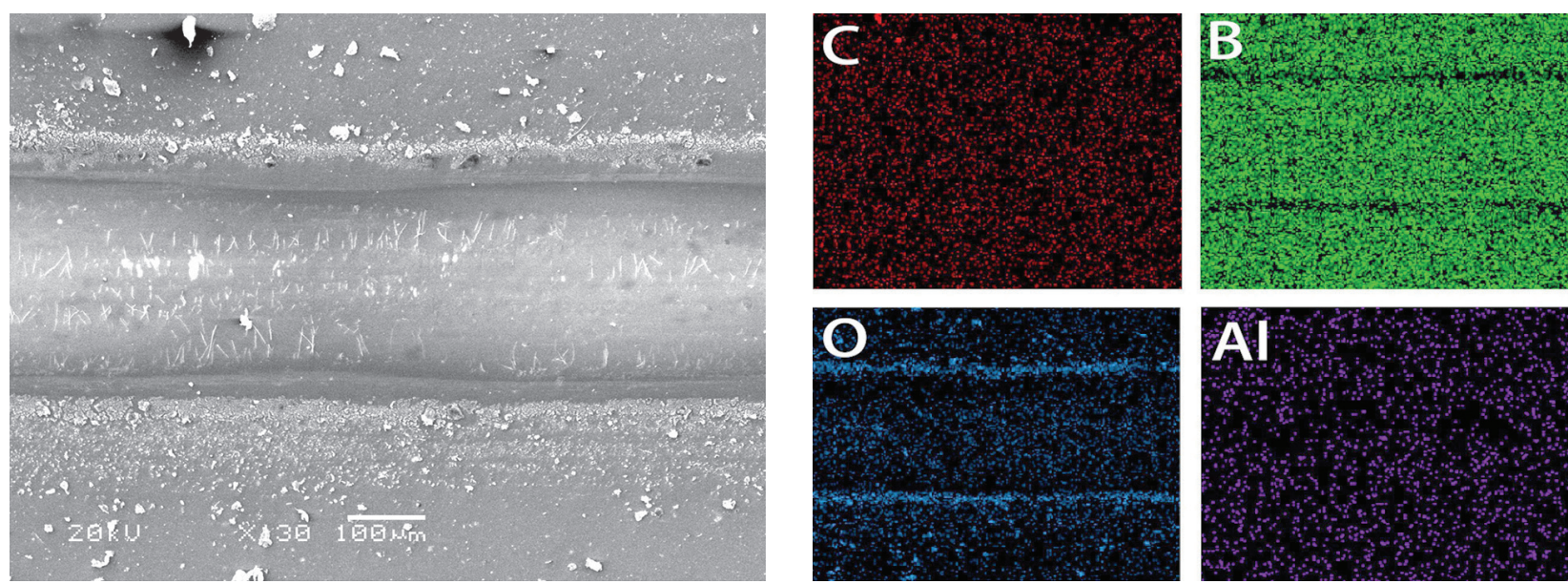

a)
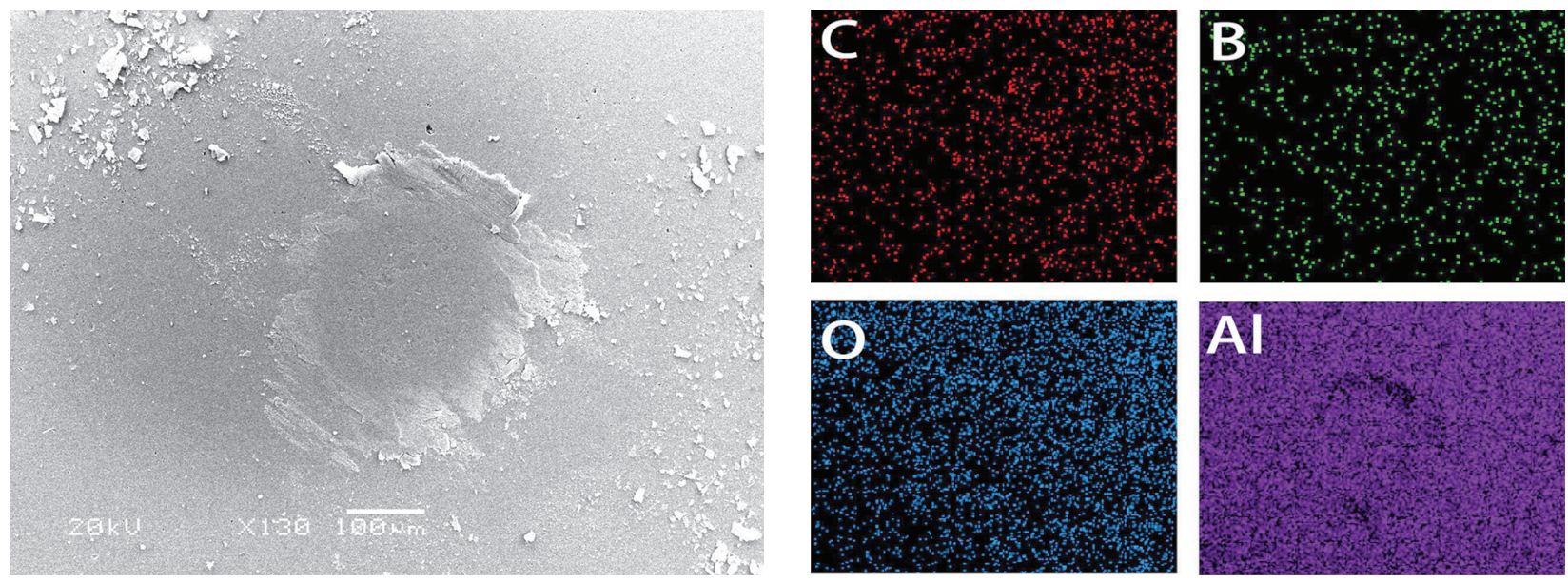

b)

Figure 9. The SEM images and EDS maps of the $\mathrm{B}_{4} \mathrm{C}$ film (a) and the $\mathrm{Al}_{2} \mathrm{O}_{3}$ ball (b) tested at $5 \mathrm{~N}, 5 \mathrm{~Hz}$ and $85 \% \mathrm{RH}$.

\section{DISCUSSION}

The average friction coefficients and wear rates under various normal loads and sliding frequencies are shown in Figure 10 to more conveniently compare the tribological performances of each tribo-pair. As shown in Figure $10 \mathrm{a}$, the $\mathrm{B}_{4} \mathrm{C} / \mathrm{WC}$ tribo-pair achieves the minimum friction coefficient and wear rate and the smallest fluctuation with the change in the normal load. In addition, from the above, the $\mathrm{B}_{4} \mathrm{C} / \mathrm{WC}$ tribo-pair also possesses very stable frictional curves and the lowest initial friction coefficient and maximum load-carrying capacity. As show in Figure 10b, the $\mathrm{B}_{4} \mathrm{C} / \mathrm{WC}$ tribo-pair also obtains the lowest friction coefficient and wear rates. Therefore, the $\mathrm{B}_{4} \mathrm{C} / \mathrm{WC}$ tribo-pair presents the best comprehensive tribological performances and is the desirable design for high humidity engineering applications.

As shown in Table 4, the comparison with present and previous tribological data provides a good insight into choosing suitable mating balls for boron carbide. In the case of $\mathrm{B}_{4} \mathrm{C}$ bulk [14, 23, 24], it is found that the
$\mathrm{B}_{4} \mathrm{C}$ bulk sliding against the WC ball achieves the minimum friction coefficient under the $50 \% \mathrm{RH}$ condition. In the case of $\mathrm{B}_{4} \mathrm{C}$ film[17], the $\mathrm{B}_{4} \mathrm{C} / \mathrm{WC}$ friction pair also obtains the lowest friction coefficient and the wear rate under the $55 \% \mathrm{RH}$ condition. In the present investigation, the $\mathrm{B}_{4} \mathrm{C} / \mathrm{WC}$ friction pair under $85 \% \mathrm{RH}$ with different normal loads achieves the lowest average friction coefficient and wear rate than those of the $\mathrm{B}_{4} \mathrm{C} / \mathrm{Al}_{2} \mathrm{O}_{3}$ and $\mathrm{B}_{4} \mathrm{C} /$ steel friction pairs. The friction coefficients of references $[15,16]$ are basically consistent with those of the $\mathrm{B}_{4} \mathrm{C} / \mathrm{Al}_{2} \mathrm{O}_{3}$ and $\mathrm{B}_{4} \mathrm{C} /$ steel friction pairs, but the wear rates are 19.8 and 7.6 times as much as those of the $\mathrm{B}_{4} \mathrm{C} / \mathrm{Al}_{2} \mathrm{O}_{3}$ and $\mathrm{B}_{4} \mathrm{C} /$ steel friction pairs, respectively. In particular, the wear rates of the references $[15,16]$ are 35.6 times higher than that of the $\mathrm{B}_{4} \mathrm{C} / \mathrm{WC}$ friction pair. Therefore, the sliding contact of the $\mathrm{B}_{4} \mathrm{C}$ film deposited by unbalanced magnetron sputtering technology sliding against the WC ball is a promising candidate for high relative humidity engineering applications.

The $\mathrm{B}_{4} \mathrm{C}$ films rubbing against three counterparts under the same conditions present different friction and wear behaviours, due largely to the tribo-chemical 
reactions of the mating materials. During the friction tests under the $85 \%$ RH condition, the oxidation product of $\mathrm{WO}_{3}$ can act as a "lubricant", and then a thin tribo-chemical film containing $\mathrm{WO}_{3}$ can be formed on the sliding interfaces. This is propitious to reduce the fric-tion coefficient and enhance the wear resistance [25-27]. While the steel ball was oxidised to form $\mathrm{Fe}(\mathrm{OH})_{3}$ which could bring about the strong adhesion at the sliding interfaces [28], and, further, results in a higher average friction coefficient of the $\mathrm{B}_{4} \mathrm{C} /$ steel tribopair. Moreover, the other oxidation products of $\mathrm{Fe}_{2} \mathrm{O}_{3}$ and $\mathrm{Fe}_{3} \mathrm{O}_{4}$ could act as "abrasives", which would lead to the relative higher average wear rates than that of the $\mathrm{B}_{4} \mathrm{C} / \mathrm{WC}$. For the $\mathrm{B}_{4} \mathrm{C} / \mathrm{Al}_{2} \mathrm{O}_{3}$ tribo-pair, the reaction rate of $\mathrm{Al}_{2} \mathrm{O}_{3}$ with $\mathrm{H}_{2} \mathrm{O}$ is very low, due to much lower free energies for the formations of aluminium trihydroxide (about $25.9 \mathrm{~kJ} \cdot \mathrm{mol}^{-1}$ ) and aluminium hydroxide (about $21.6 \mathrm{~kJ} \cdot \mathrm{mol}^{-1}$ ) [29]. And $\mathrm{Al}_{2} \mathrm{O}_{3}$ (a Lewis acid) has often been used as a catalyst for the degradation of hydrocarbon polymers $[30,31]$, which could bring about the degradation of the DLC film [28]. Similar degradation might also occur on the $\mathrm{B}_{4} \mathrm{C}$ film, i.e., lots of abrasive grains and many small cracks inside the disc wear track (shown in Figure 9a). And hence, the $\mathrm{B}_{4} \mathrm{C} / \mathrm{Al}_{2} \mathrm{O}_{3}$ tribopair achieves the highest average friction coefficient and wear rate.

Here we discuss the influence of the normal load (contact pressure) on the tribological performances. According to the Hertzian elastic contact model, the friction coefficient $\mu$ of the ball-on-disk mode can be expressed as a function of the normal load $\mathrm{F}_{\mathrm{N}}$ :

$$
\mu=S_{0} \cdot \pi\left(\frac{3 R}{4 E^{*}}\right)^{2 / 3} F_{\mathrm{n}}^{-1 / 3}+\alpha
$$

in which $S_{0}$ is the interfacial shear strength of the friction pair at zero load, $E^{*}$ is the composite elastic modulus of the friction pair, $R$ is the radius of the counter ball and the constant $\alpha$ represents the pressure dependence of the shear strength $[32,33]$. In the range of elastic deformation, Equation 1 suggests that the coefficient of friction decreases when the applied load increases. Once high contact pressure results in the plastic deformation of the substrate material, Jungk et al. [34] proposed that the friction coefficient will increase with the increase

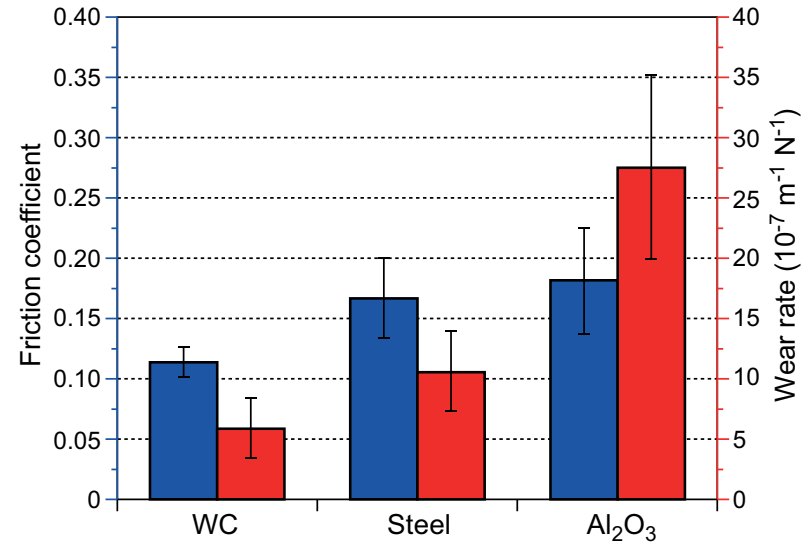

a) normal load

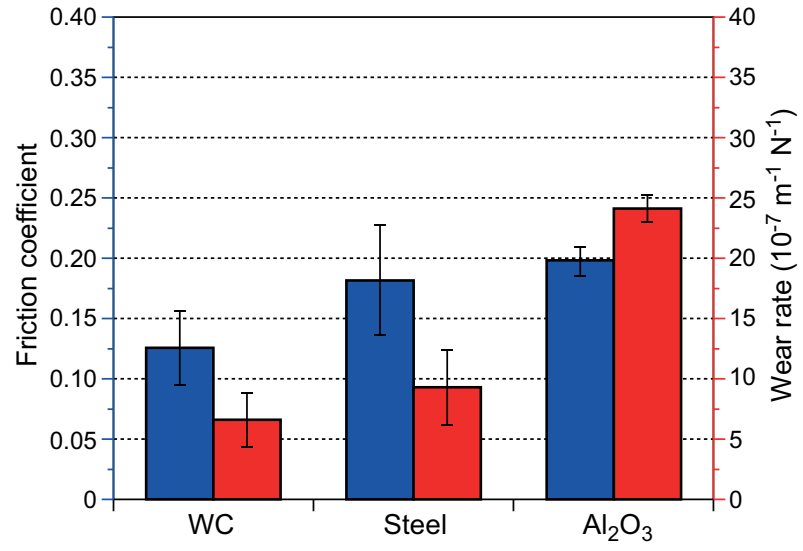

b) frequency

Figure 10. The average friction coefficient and wear rate of each tribo-pair under different normal loads (a) and sliding frequencies (b).

Table 4. The coefficient of friction $(\mathrm{CoF})$ and wear rate $\left(10^{-7} \mathrm{~mm}^{3} \cdot \mathrm{m}^{-1} \cdot \mathrm{N}^{-1}\right)$ of boron carbide (film or bulk) sliding against various mating materials.

\begin{tabular}{|c|c|c|c|c|c|c|c|c|}
\hline Material & Counterpart & Ball on disk & RH (\%) & Load $(\mathrm{N})$ & Speed $\left(\mathrm{m} \cdot \mathrm{s}^{-1}\right)$ & $\mathrm{CoF}$ & Wear rate & Reference \\
\hline $\mathrm{B}_{4} \mathrm{C}$ bulk & $440 \mathrm{C}$ steel & rotating mode & 50 & 5 & 0.005 & 0.7 & - & {$[14]$} \\
\hline $\mathrm{B}_{4} \mathrm{C}$ bulk & $\mathrm{ZrO}_{2}$ & rotating mode & 50 & 5 & $0.05-0.08$ & 0.3 & - & [23] \\
\hline $\mathrm{B}_{4} \mathrm{C}$ bulk & WC & reciprocating mode & 50 & 3 & 0.02 & 0.202 & 1.61 & {$[24]$} \\
\hline \multirow{3}{*}{$\mathrm{B}_{4} \mathrm{C}$ film } & $\mathrm{WC}$ & & 55 & 2 & 0.05 & 0.22 & 1.64 & \multirow{3}{*}[17]{} \\
\hline & Steel & reciprocating mode & 55 & 2 & 0.05 & 0.71 & 12.26 & \\
\hline & $\mathrm{Al}_{2} \mathrm{O}_{3}$ & & 55 & 2 & 0.05 & 0.78 & 23.91 & \\
\hline \multirow{3}{*}{$\mathrm{B}_{4} \mathrm{C}$ film } & WC & & 85 & $1-15$ & 0.05 & 0.11 & 0.59 & \multirow{3}{*}{$\begin{array}{l}\text { Present } \\
\text { study }\end{array}$} \\
\hline & Steel & reciprocating mode & 85 & $1-10$ & 0.05 & 0.17 & 1.06 & \\
\hline & $\mathrm{Al}_{2} \mathrm{O}_{3}$ & & 85 & $1-7$ & 0.05 & 0.18 & 2.76 & \\
\hline $\mathrm{B}_{4} \mathrm{C}$ film & Ti-6Al-4V & - & 85 & 2 & 0.02 & 0.18 & 22 & [15] \\
\hline $\mathrm{B}_{4} \mathrm{C}$ bulk & $\mathrm{B}_{4} \mathrm{C}$ & rotating mode & 100 & 15 & 1.0 & 0.15 & 20 & {$[16]$} \\
\hline
\end{tabular}


in the normal load. The critical contact stress, only related to the mechanical properties of the given tribopair, should be a constant in the specific environment. Therefore, with the increase in the normal load, the friction coefficients of the three friction pairs increase at first and then decrease.

The temperature of some contact points can rise to several hundred degrees due to the micro-roughness of the contact surface and the heat generated by the friction. The faster sliding frequency is, the higher the probability of the friction repetition at the same point, and the shorter time for heat diffusion is, and, thus, it will be a higher temperature, which is propitious to the tribo-chemical reaction of the $\mathrm{B}_{4} \mathrm{C}$ films and mating balls. For the $\mathrm{B}_{4} \mathrm{C} / \mathrm{WC}$ tribo-pair and the $\mathrm{B}_{4} \mathrm{C} /$ Steel tribopair, the tribo-chemical products can produce a smooth surface and avoid the direct contact with the friction pair, which could lead to fewer abrasive particles and then effectively reduce the friction coefficient and wear rate. There is no tribo-chemical reaction for $\mathrm{Al}_{2} \mathrm{O}_{3}$, thus, the friction coefficient and wear rate are less affected by the sliding frequency, and only slightly decrease.

\section{CONCLUSIONS}

From the above, the tribo-chemical reactions of the counterpart balls have a significant influence on the tribological behaviours of the $\mathrm{B}_{4} \mathrm{C}$ film under $85 \% \mathrm{RH}$ with various normal loads and sliding frequencies and the conclusions are as follows:

- The $\mathrm{B}_{4} \mathrm{C} / \mathrm{WC}$ tribo-pair presents the outstanding comprehensive tribological performances, including the minimum friction coefficients \& wear rates, maximum load carrying capacity and the smallest fluctuation with the change in the normal load and sliding frequencies. This is mainly attributed to the tribo-chemical product of $\mathrm{WO}_{3}$.

- With an increasing normal load, the friction coefficients and wear rates of each tribo-pair decrease at first and then increase. The lowest values are obtained at $5 \mathrm{~N}(\mathrm{WC}), 5 \mathrm{~N}$ (Steel) and $3 \mathrm{~N}\left(\mathrm{Al}_{2} \mathrm{O}_{3}\right)$, respectively.

- The friction coefficients and wear rates of each tribo-pair decrease with the increase in the sliding frequency. This is mainly attributed to the fact that the high sliding frequency promotes the tribo-chemical reaction of the $\mathrm{B}_{4} \mathrm{C}$ films and mating balls, which is conducive to the formation of the tribo-chemical films.

\section{Acknowledgments}

The authors are grateful for the financial support from National Key R\&D Programme of China (No. 2018YFB0703801) and the National Natural Science Foundation of China (No. 51775535).

\section{REFERENCES}

1. Tan D. W., Guo W. M., Wang H. J., Lin H. T., Wang C. Y. (2018): Cutting performance and wear mechanism of $\mathrm{TiB}_{2}-\mathrm{B}_{4} \mathrm{C}$ ceramic cutting tools in high speed turning of $\mathrm{Ti}_{6} \mathrm{Al}_{4} \mathrm{~V}$ alloy. Ceramics International, 44, 15495-15502. doi:10.1016/j.ceramint.2018.05.209

2. Deng J. X. (2005): Erosion wear of boron carbide ceramic nozzles by abrasive air-jets. Materials Science and Engineering a-Structural Materials Properties Microstructure and Processing, 408, 227-233. doi:10.1016/j.msea.2005. 07.029

3. Singam P. S., Nayak M., Gupta R., Pradhan P. C., Majhi A., Narendranath S., Sreekumar P. (2018): Thermal and temporal stability of $\mathrm{W} / \mathrm{B} 4 \mathrm{C}$ multilayer mirrors for space-based astronomical applications. J. Astron. Telesc. Instrum. Syst., 4, 8. doi:10.1117/1.jatis.4.4.044003

4. Jarvis E. (2003): High-velocity ballistic impact with boron carbide produces localized amorphization. Mrs Bulleti, 28, 333-333. doi:10.1557/mrs2003.91

5. Croci, G., Muraro, A., Cippo, E. P., Tardocchi, M., Grosso, G., Albani, G., Angella, G., Defendi, I., Hall-Wilton, R., Hoglund, C., Raspino, D., Rhodes, N., Robinson, L., Schmidt, S., Schooneveld, E., Zeitelhack, K. and Gorini, G. (2018): A high-efficiency thermal neutron detector based on thin 3D (B4C)-B-10 converters for high-rate applications. Europhysics Letters, 123, 52001.doi: 10.1209/ 0295-5075/123/52001

6. Alizadeh A., Taheri-Nassaj E. (2011): Wear Behavior of Nanostructured Al and Al-B4C Nanocomposites Produced by Mechanical Milling and Hot Extrusion. Tribology Letters, 44,59-66. doi:10.1007/s11249-011-9825-3

7. Zhang Z., Topping T., Li Y., Vogt R., Zhou Y., Haines C., Paras J., Kapoor D., Schoenung J. M., Lavernia E. J. (2011): Mechanical behavior of ultrafine-grained Al composites reinforced with B4C nanoparticles. Scripta Materialia, 65, 652-655. doi:10.1016/j.scriptamat.2011.06.037

8. Singh D. K., Tripathi M. K., Singh V. B. (2015): Electrolytic Preparation of Ni-B4C Composite Coating and its Characterization. Journal of Materials Engineering and Performance, 24,1213-1219. doi:10.1007/s11665-015-1396-2

9. Domnich V., Reynaud S., Haber R. A., Chhowalla M. (2011): Boron Carbide: Structure, Properties, and Stability under Stress. Journal of the American Ceramic Society, 94,3605-3628. doi:10.1111/j.1551-2916.2011.04865.x

10. Thévenot F. (1990): Boron carbide - A comprehensive review. Journal of the European Ceramic Society, 6, 205-225. doi:10.1016/0955-2219(90)90048-K

11. Reddy K. M., Guo J. J., Shinoda Y., Fujita T., Hirata A., Singh J. P., McCauley J. W., Chen M. W. (2012): Enhanced mechanical properties of nanocrystalline boron carbide by nanoporosity and interface phases. Nature Communications, 3, 1052. doi:10.1038/ncomms2047

12. Gao S. B., Li X., Wang S., Xing P. F., Kong J., Yang G. P. (2019): A low cost, low energy, environmentally friendly process for producing high-purity boron carbide. Ceramics International, 45,3101-3110. doi:10.1016/j.ceramint.2018.10. 202

13. Murthy T. S. R. C., Ankata S., Sonber J. K., Sairam K., Singh K., Nagaraj A., Sengupta P., Bedse R. D., Majumdar S., Kain V. (2018): Microstructure, thermo-physical, mechanical and wear properties of in-situ formed boron carbidezirconium diboride composite. Ceramics-Silikáty, 62(1), 15-30. doi:10.13168/cs.2017.0041 
14. Erdemir A., Bindal C., Fenske G. R. (1996): Formation of ultraflow friction surface films on boron carbide. Applied Physics Letters, 68,1637-1639. doi:10.1063/1.115676

15. Bhowmick S., Sun G., Alpas A. T. (2016): Low friction behaviour of boron carbide coatings (B4C) sliding against Ti-6Al-4V. Surface \& Coatings Technology, 308, 316-327. doi:10.1016/j.surfcoat.2016.05.092

16. Larsson P., Axén N., Hogmark S. (1999): Tribofilm formation on boron carbide in sliding wear. Wear, 236,73-80. doi:10.1016/s0043-1648(99)00266-5

17. Cao X., Shang L., Liang Y., Lu Z., Zhang G., Xue Q. (2019): The effect of tribo-chemical reactions of mating materials on tribological behaviors of the $\mathrm{B}_{4} \mathrm{C}$ film in various relative humidity environments. Ceramics International, 45, 4581-4589. doi:10.1016/j.ceramint.2018.11.145

18. Ahn H. S., Cuong P. D., Shin K. H., Lee K. S. (2005): Tribological behavior of sputtered boron carbide coatings and the influence of processing gas. Wear, 259, 807-813. doi:10.1016/j.wear.2005.02.096

19. Li X., Gao Y., Pan W., Zhong Z., Song L., Chen W., Yang Q. (2014): Effect of hBN content on the friction and wear characteristics of $\mathrm{B} 4 \mathrm{C}-\mathrm{hBN}$ ceramic composites under dry sliding condition. Ceramics International, 41, 3918-3926. doi:10.1016/j.ceramint.2014.11.074

20. Li X., Gao Y., Song L., Yang Q., Wei S., You L., Zhou Y., Zhang G., Xu L., Yang B. (2018): Influences of hBN content and test mode on dry sliding tribological characteristics of $\mathrm{B} 4 \mathrm{C}-\mathrm{hBN}$ ceramics against bearing steel. Ceramics International, 44,6443-6450. doi:10.1016/j.ceramint. 2018.01.039

21. Li X., Gao Y., Yang Q. (2017): Sliding tribological performance of $\mathrm{B} 4 \mathrm{C}-\mathrm{hBN}$ composite ceramics against AISI 321 steel under distilled water condition. Ceramics International, 43,14932-14937. doi:10.1016/j.ceramint.2017.08. 010

22. Cuong P. D., Ahn H. S., Yoon E. S., Shin K. H. (2006): Effects of relative humidity on tribological properties of boron carbide coating against steel. Surface \& Coatings Technology, 201,4230-4235. doi:10.1016/j.surfcoat.2006. 08.093

23. Erdemir A., Bindal C., Zuiker C., Savrun E. (1996): Tribology of naturally occurring boric acid films on boron carbide. Surface \& Coatings Technolog, s 86-87,507-510. doi:10.1016/s0257-8972(96)02984-2

24. Sonber J. K., Limaye P. K., Murthy T. S. R. C., Sairam K., Nagaraj A., Soni N. L., Patel R. J., Chakravartty J. K. (2015): Tribological properties of boron carbide in sliding against WC ball. International Journal of Refractory
Metals \& Hard Materials, 51,110-117.doi:10.1016/j.ijrmhm. 2015.03.010

25. He D., Pu J., Lu Z., Wang L., Zhang G., Xue Q. (2017): Simultaneously achieving superior mechanical and tribological properties in WC/a-C nanomultilayers via structural design and interfacial optimization. Journal of Alloys and Compounds, 698,420-432.doi:10.1016/j.jallcom.2016. 12.173

26. Pu J., He D., Wang L. (2015): Effects of WC phase contents on the microstructure, mechanical properties and tribological behaviors of WC/a-C superlattice coatings. Applied Surface Science, 357, 2039-2047. doi:10.1016/j. apsusc.2015.09.181

27. Tamura Y., Zhao H., Wang C., Morina A., Neville A. (2016): Interaction of DLC and B4C coatings with fully formulated oils in boundary lubrication conditions. Tribology International, 93, 666-680.doi:10.1016/j.triboint. 2015.02.029

28. Li H., Xu T., Wang C., Chen J., Zhou H., Liu H. (2005): Tribochemical effects on the friction and wear behaviors of diamond-like carbon film under high relative humidity condition. Tribology Letters, 19, 231-238.doi:10.1007/ s11249-005-6150-8

29. Rani D. A., Yoshizawa Y., Hyuga H., Hirao K., Yamauchi, Y. (2004): Tribological behavior of ceramic materials $\left(\mathrm{Si}_{3} \mathrm{~N}_{4}, \mathrm{SiC}\right.$ and $\left.\mathrm{Al}_{2} \mathrm{O}_{3}\right)$ in aqueous medium. Journal of the European Ceramic Society, 24, 3279-3284. doi:10.1016/j. jeurceramsoc.2003.11.020

30. Lin Y. H., Yang M. H., Yeh T. F., Ger M. D. (2004): Catalytic degradation of high density polyethylene over mesoporous and microporous catalysts in a fluidised-bed reactor. Polymer Degradation \& Stability, 86, 121-128. doi:10.1016/j.polymdegradstab.2004.02.015

31. Qu J., Li H., Liu H., He H. (2004): Ozonation of alachlor catalyzed by Cu/AlO in water, Catalysis Today, 90,291-296. doi:10.1016/j.cattod.2004.04.032

32. Mohrbacher H., Celis J. P. (1995): Friction mechanisms in hydrogenated amorphous carbon coatings. Diamond \& Related Materials, 4,1267-1270. doi:10.1016/0925-9635(95) 00306-1

33. Singer I. L., Bolster R. N., Wegand J., Fayeulle S., Stupp B. C. (1990): Hertzian stress contribution to low friction behavior of thin $\mathrm{MoS}_{2}$ coatings. Applied Physics Letters, 57, 995-997. doi:10.1063/1.104276

34. Jungk J. M., Michael J. R., Prasad S. V. (2008): The role of substrate plasticity on the tribological behavior of diamond-like nanocomposite coatings. Acta Materialia, 56,1956-1966. doi:10.1016/j.actamat.2007.12.048 